\title{
Regional Construction Manpower Projection Models: Michigan - A Case Study\#
}

\author{
John M. MatTila* and James R. Moor, JR.**
}

Shortages and surpluses of skilled manpower, whether current or future, real or imagined, have created an urgent need for formal manpower planning at both the national and local levels. National manpower planning has been actively undertaken for the past twenty years, not only in this country but in many other countries throughout the world. ${ }^{1}$ It is only in the last few years, however, that there has been a sufficiently intense concern for manpower planning at the local level to require and support development of formal manpower projection models for sub-state regions.

Well-known construction manpower expert Daniel Quinn Mills ${ }^{2}$ has noted the relatively primitive "state of the art" of local manpower planning. Mills emphasizes that the cost and difficulty of obtaining reliable local area data is a major constraint confronting local manpower planning projects. As a result, while acceptable methods of preparing manpower demand estimates have been fully applied on a national and multi-state regional basis, they have yet to be adapted to local area manpower planning needs. ${ }^{3}$ Consequently, the local area study which provides the basis for this paper-The Michigan Building and Construction Trades Craft Manpower Study (hereafter called The Michigan Craft Study) ${ }^{4}$-was designed to eliminate some of these shortcomings. The result is, hopefully, a more useful tool for local construction manpower planning.

To the best of our knowledge, the Michigan Craft Study is the first such local area manpower study to:

1. use a local, econometric model as an integral part of a manpower study for the purpose of generating endogenous, simultaneously derived, industry employment projections;

2. construct local industry-occupational matrices for the purpose of converting industry employment projections into craft employment projections. Previous studies have either relied on national industry-occupational matrices or, at best, on slightly modified national tables; ${ }^{5}$

3. use local craft actuarial data to derive local craft-specific replacement rates.

\#The authors are indebted to the many people of Michigan's construction industry whose cooperation made this Study possible. Special thanks are due the Citizens Research Council of Michigan and the Advisory Committee of construction industry experts, who marshalled the financial support for our work, and to Nurit Ruthenberg and Christopher Klisz for their able assistance.

*Professor of Economics, Wayne State University.

**Assistant Professor of Economics, Central Michigan University. 
In Michigan, the demand for formal manpower planning first manifested itself in the needs of the Detroit Edison and Consumers Power Companies, which anticipated rapidly accelerating power plant construction into the 1980's long before the current "energy problem" arose. The Citizens Research Council of Michigan brought together the concerned power plant construction managers with industrial relations experts from several construction contractor's associations and with members of the construction trades councils in Detroit and Michigan, to act as an Advisory Committee to the Michigan Craft Study.

The Advisory Committee members identified the following nine trades that were in potential short supply in some, if not all, of ten multi-county manpower planning regions in the State: Asbestos Workers, Boilermakers, Carpenters, Electricians, Ironworkers, Millwrights, Operating Engineers, Plumbers and Pipefitters, and Sheetmetal Workers. The ten regions are identified in Chart 1.

This paper is a report on the methodology that was developed at Wayne State University for making relevant long-term regional construction manpower projections to 1980 for these manpower planning regions. While the authors include some of the specific findings for the seven-county Detroit Region and the State of Michigan as a whole for illustrative purposes, the paper is intended to highlight the Study's contribution to the "state of the art" of local manpower planning rather than merely reporting local construction manpower projections. ${ }^{6}$

The broad outlines of the Study do not differ significantly from those employed by Federal manpower experts in making comprehensive national projections, nor from the approach suggested by Daniel Quinn Mills for local manpower planning. ${ }^{7}$ Most all precedent studies include the following four major stages of development:

1. Generation of aggregate population and employment projections for the nation (region) or the inclusion of existing projections from some existing and acceptable source.

2. Generation of specific (construction) industry employment projections as a function of aggregate regional economic growth.

3. Conversion of those industry employment projections into occupational (craft) projections through the use of an appropriate industry-occupation matrix.

4. Projecting the "supply" of each craft by region and comparing those supply projections with the occupational ("demand") projections for potential shortages or surpluses.

While this approach was found to be quite satisfactory for creating regional construction manpower projections models, there was a severe shortage of both the tools and the materials with which to begin. Consequently, a substantial amount of time and effort had to be devoted to the task of marshalling resources. This involved not only custom building the various modules of each projection model, but also extensive data gathering and methodological design, all necessary to assemble and estimate those models. The evolution of the Study will be discussed in terms of the above major stages of development. 


\section{CRAFT MANPOWER STUDY REGIONS}

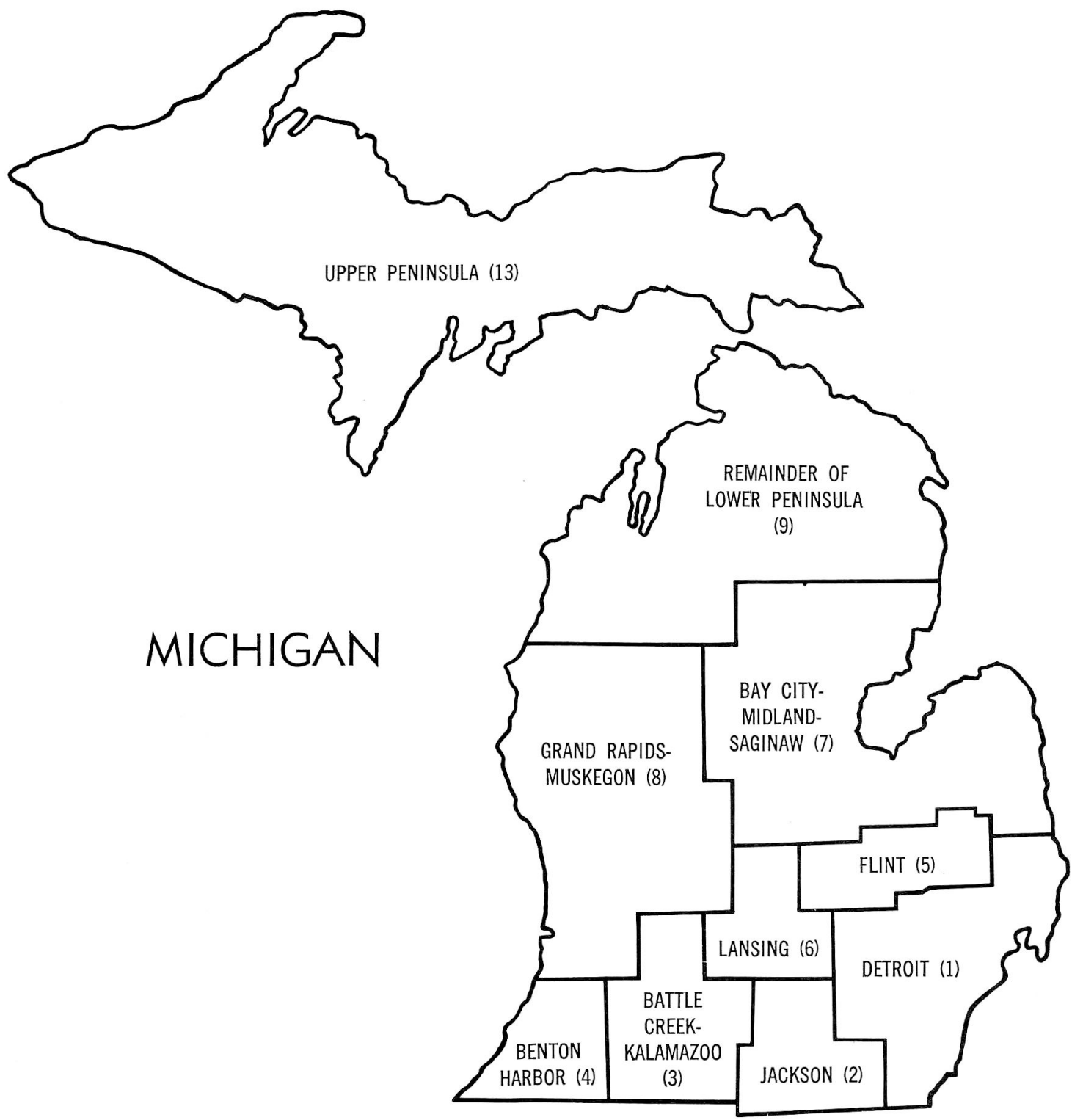




\section{Generation of Aggregate Population and Employment Projections for Each Region}

There is a growing awareness among both demographers and economists that population growth has key economic determinants at the regional level, where migration plays such an important role in population forecasting. Many urban and regional simulation models have already incorporated population forecasting as an integral part of their employment, housing and land-use modules. Recognizing the constraints of time as well as the existence of recently prepared State population projections by county (available from the 1973 Economic Report of the Governor), the Study accepted outside population estimates without attempting to generate its own projections. Bringing the population projection process into the model thus became an important "future" step in the regional modeling effort.

Next, regional and State-wide employment projections were generated with ten regional econometric models, primarily using population and industry employment data. Since these models simultaneously generated the construction industry employment projections, their development is discussed concurrently, in the next section.

\section{Generation of Construction Industry Employment Projections by Region}

An econometric model was developed for each planning region in Michigan based, in large part, on the widely-accepted export-base theory of regional growth and development. The model identified three distinct industrial sectors in each region, as defined by that sector's primary function-export, local or construction. For the purpose of the Study, export industries were defined as those industries which produce a significant portion of their output for sale beyond the region's boundaries; local industries are those which produce primarily for the local market (including government in most cases). Of course the construction industry, which is normally a part of the local sector, is isolated for separate and more detailed attention. The various industrial categories within the construction sector are identified in Table 1. To specify the general functional form of the equations which make up each regional econometric model, reference will be made to the variables which are used to calibrate those models which are detailed in Tables 2, 3 and 4.

The key export industries unique to each region were identified and the level of their activity (measured by employment, e.g., motor vehicles-EMV) was made a function of exogenously determined national demand for the industry's output (measured by U.S. value of shipments, e.g., motor vehicle shipments-SHMV). The level of activity in the local sector, which includes the remaining private, nonconstruction industries (ELOSR) as well as public employment (EPUB), were next expressed as functions of the level of aggregate export activity (EEXP), population (POP) and both lagged (LELOSR) and contemporaneous changes among those local sector industries. As a result, the level of regional activity, exclusive of the construction sector, is captured by the inter-industry relationships which exist within the region and is linked to the level of national activity through the region's export industries. 
TABLE 1 INDUSTRIAL CLASSIFICATIONS FOR THE
CONSTRUCTION INDUSTRY

\begin{tabular}{|c|c|c|c|}
\hline $\begin{array}{l}\text { Two-Digit } \\
\text { SIC Code }\end{array}$ & $\begin{array}{l}\text { Three-Digit } \\
\text { SIC Code }\end{array}$ & Definition of Classification & $\begin{array}{c}\text { Study } \\
\text { Abbreviation }\end{array}$ \\
\hline $15-17$ & & Contract Construction Industry & CONST \\
\hline 15 & 151 & General Building Contractors & GBC \\
\hline \multirow[t]{3}{*}{16} & & Heavy Contract Construction & $\mathrm{HCC}$ \\
\hline & 161 & Highway and Street Construction & \\
\hline & 162 & Heavy Construction, nec ${ }^{*}$ & \\
\hline \multirow[t]{11}{*}{17} & & Special Trade Contractors & SPEC \\
\hline & 171 & $\begin{array}{l}\text { Plumbing, Heating (except } \\
\text { electric) and Air Conditioning }\end{array}$ & $\mathrm{PHC}$ \\
\hline & 173 & Electrical Work Contractors & EWC \\
\hline & 175 & Carpentering \& Flooring Contractors & CFT \\
\hline & $172,4,6-9$ & Miscellaneous Trade Contractors & MTC \\
\hline & 172 & Painting, Paper Hanging \& Decorating & \\
\hline & 174 & Masonry, Stonework \& Plastering & \\
\hline & 176 & Roofing and Sheetmetal Work & \\
\hline & 177 & Concrete Work & \\
\hline & 178 & Water Well Drilling & \\
\hline & 179 & Other Special Trade Contractors & \\
\hline
\end{tabular}

*Not elsewhere classified.

Source: Executive Office of the President, Bureau of the Budget, Standard Industrial Classification Manual, 1967.

Since the national demand for each region's exports was measured by the value of shipments, an income measure would be the most logical variable to be used as a measure of the local level of activity. Metropolitan income estimates by industry of origin were available for the Detroit metropolitan area ${ }^{8}$ and were used in calibrating the model. In the absence of a comparable measure for the other regions, employment was used in all of the remaining models.

In the construction sector, the level of employment for general building contractors' (GBC) was made a function of the level of current and lagged activity in the non-construction sectors. Heavy contract construction (HCC) frequently turned out to be a function of population change and/or a time trend factor (TIME). Employment for each of four categories of special trades contractors 
(SPEC) was determined jointly by the level of activity of the general building contractors and in the non-construction sectors of the region. The various functional forms discussed above can be summarized as follows:

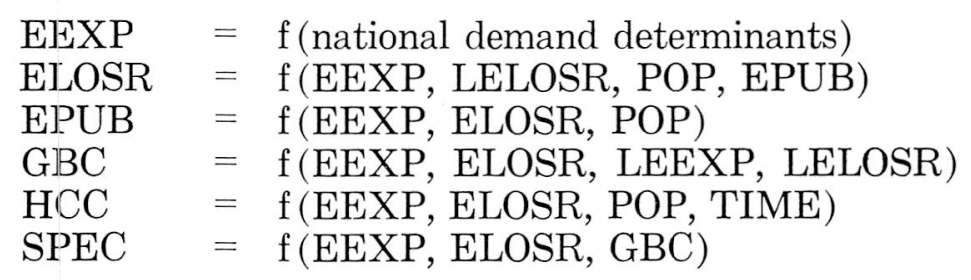

The parameters of each model were estimated by ordinary and two-stage least squares using annual county population data prepared by the Health Planning Council of Michigan, employment data from the Michigan Employment Security Commission and value of shipments data from the U.S. Department of Commerce deflated to 1967 dollars. The data was obtained from the years 1959-1972. Tables 2 and 3 detail the structural equations of the industry employment models for Detroit and the State of Michigan, respectively, while Table 4 defines the variable abbreviations used in those and the other models.

While it is not possible, in this brief paper, to provide a detailed rationale for each of the individual regional models or even for the Detroit and State models which are presented in Tables 2 and 3, a few general comments are in order. The export and local industry mix and growth rates vary significantly among regions in the State and, therefore, have differential impacts on the construction industries in each region. Stable or declining industries do not generate significant demand for construction and consequently necessitate some variation in the specification of the models from region to region. Since the primary objective of this study was to generate accurate projections rather than to focus on individual parameters which might be interpreted as elasticity or propensity coefficients, there was an admitted bias toward the maximization of $\mathrm{R}^{2}$ (the multiple regression coefficient of determination). This pragmatic but appropriate approach also resulted in some individualization of the structural equations by regions. Nevertheless, the discerning reader will agree that all of the models do conform to the general specification given above.

Population projections from the 1973 Economic Report of the Governor and three alternative projected national growth rates for industrial shipments (high, medium and low), as published by the U.S. Department of Commerce, provided forecasts of the model's exogenous variables. The reduced form solution for each model was then used to make three alternative sets of annual industry employment projections to 1980 . Tables 5 and 6 present the results of these projections for the Detroit Region and for the State of Michigan.

\section{Conversion of the Industry Employment Projections Into Craft Employment Projections}

At least two alternative methods are available for converting construction industry manpower projections into projections by craft depending on the level of 
Export Sector

\begin{tabular}{|c|c|c|c|}
\hline (1.1) & YMV & $=$ & $\begin{array}{c}-571971.9 \\
(-3.10)\end{array}+\underset{(2.24)}{.138604 \mathrm{LYMV}}+\underset{(15.17)}{95.95503 \mathrm{SHMV}}$ \\
\hline (1.2) & YMACH & $=$ & $\begin{array}{c}-570941.1 \\
(-4.18)\end{array}+\underset{(7.13)}{.521356 \mathrm{LYMACH}}+\underset{(7.16)}{1.656337 \mathrm{YPRIM}}$ \\
\hline (1.3) & YFBM & $=$ & $\underset{(-0.14)}{-6301.7}+\underset{(6.87)}{.0747646 \mathrm{YMV}}+\underset{(7.87)}{.4055166 \mathrm{YMACH}}$ \\
\hline (1.4) & YPRIM & $=$ & $\begin{array}{c}347626.6 \\
(5.32)\end{array}$ \\
\hline (1.5) & YCHEM & $=$ & $\begin{array}{c}65442.4 \\
(4.77)\end{array}+\begin{array}{c}.05840035 \mathrm{PRIM} \\
(2.73)\end{array}$ \\
\hline
\end{tabular}

$\mathrm{N}=13$
$\mathrm{SE}=138,640$
$\mathrm{~N}=13$
$\mathrm{SE}=51,014$
$\mathrm{~N}=13$
$\mathrm{SE}=27,238$
$\mathrm{~N}=13$
$\mathrm{SE}=42,175$
$\mathrm{~N}=13$
$\mathrm{SE}=5,097$

$\mathrm{R}^{2}=.98$

$\mathrm{DW}=.98$

$\mathrm{R}^{2}=.95$

$\mathrm{DW}=2.48$

$\mathrm{R} 2=.97$

$\mathrm{R}^{2}=.72$

$\begin{array}{ll}\mathrm{R} 2 & =.72 \\ \mathrm{DW} & =1.19\end{array}$

$\mathrm{R}^{2}=.98$

Local Sector
(1.6) YLOSR
$=\underset{(0.60)}{130578.3}+\underset{(16.84)}{.7946966 \mathrm{LYLOSR}}+\underset{\text { (2166688Y }}{.252)}$
6.52)
(1.7) YPUB
$=\underset{(-2.34)}{-169730.4}+\underset{(10.75)}{.8079766 \mathrm{LYPUB}}+\underset{\text {.0720361YLOSR }}{(3.11)}$
$\mathrm{N}=13$
$\mathrm{SE}=108,107$
$\mathrm{N}=13$

$\mathrm{SE}=23,103$

$\mathrm{R} 2=.99$

$\mathrm{R}^{2}=.99$

Construction Sector

\begin{tabular}{ll} 
(1.8) & GBC \\
(1.9) & LOGHCC \\
(1.10) & PHC \\
(1.11) & EWC \\
(1.12) & CFT \\
\hline &
\end{tabular}
$=\underset{(-3.68)}{-10268.8}+\underset{(5.57)}{.0053815 Y L O S R}-.00983726$ YPUB

$$
\text { (5.57) }
$$$$
(-3.25)
$$

$\mathrm{N}=13$
$\mathrm{SE}=766$

$\mathrm{N}=14$

$(339.85) \quad(-2.80)$
$-926.1+.3998175$

$=\underset{(-1.27)}{-926.1}+.3998175 \mathrm{LPHC}+.4114422 \mathrm{GBC}$

$=-1833.7+.4892429 \mathrm{LEWC}+.3558911 \mathrm{GBC}$

$(-2.35) \quad$ (3.64) (3.85)

$=-2598.3+.14059174 \mathrm{GBC}+.08523673 \mathrm{LGBC}+.00121528 \mathrm{YLOSR}-.00083050 \mathrm{LYLOSR}$

$\begin{array}{lc}(2.54) & (-1.75) \\ \text { YLOSR } & -.00128620 \text { LYLOSR }\end{array}$

$\mathrm{SE}=.0703743$

$\mathrm{N}=13$

$\mathrm{SE}=461$

$\mathrm{N}=13$

$\mathrm{SE}=455$

$\mathrm{N}=13$

$\mathrm{SE}=243$

$\mathrm{N}=13$

$\begin{gathered}440.5 \\ (0.41)\end{gathered}+\begin{array}{r}.6836347 \mathrm{C} \\ (3.75)\end{array}$

(0.73)

(2.22)

$(-1.33)$

$\mathrm{N}=13$
$\mathrm{SE}=498$

$\mathrm{DW}=1.88$

( $t$-values in parentheses) 
SIMULATION MODEL FOR CONSTRUCTION INDUSTRY EMPLOYMENT - STATE OF MICHIGAN

Export Sector

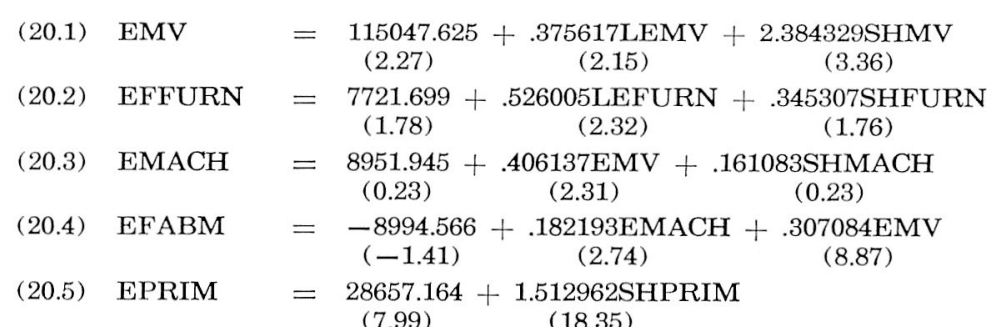

$$
\begin{aligned}
& N=13 \\
& \mathrm{SE}=19,932 \\
& \mathrm{~N}=13 \\
& \mathrm{SE}=1103 \\
& \mathrm{~N}=13 \\
& \mathrm{SE}=11,651 \\
& \mathrm{~N}=13 \\
& \mathrm{SE}=2381 \\
& \mathrm{~N}=14 \\
& \mathrm{SE}=1754
\end{aligned}
$$

$\mathrm{N}=13$

$\mathrm{SE}=11,162$

$\mathrm{N}=13$

$\mathrm{SE}=5588$
(31.66)
(20.6) ELOSR
(20.7) EPUB$$
\text { (31.63) }
$$$$
(-1.00)
$$$$
\text { (31.66) }
$$

$$
\begin{aligned}
& \mathrm{R} 2=.76 \\
& \mathrm{DW}=1.36 \\
& \mathrm{R} 2=.62 \\
& \mathrm{DW}=1.75 \\
& \mathrm{R}^{2}=.70 \\
& \mathrm{DW}=1.48 \\
& \mathrm{R}^{2}=.98 \\
& \mathrm{DW}=1.60 \\
& \mathrm{R}^{2}=.97 \\
& \mathrm{DW}=2.15
\end{aligned}
$$

(20.13) MTC

$$
\begin{aligned}
& \mathrm{N}=13 \\
& \mathrm{SE}=1683 \\
& \mathrm{~N}=13 \\
& \mathrm{SE}=882 \\
& \mathrm{~N}=13 \\
& \mathrm{SE}=431 \\
& \mathrm{~N}=13 \\
& \mathrm{SE}=409 \\
& \mathrm{~N}=13 \\
& \mathrm{SE}=257 \\
& \mathrm{~N}=13 \\
& \mathrm{SE}=645
\end{aligned}
$$

$$
=\underset{(-2.90)}{-12337.938}+.451974 \mathrm{GBC}+.013173 \mathrm{ELOSR}+.014937 \mathrm{EEXP}
$$

$$
\begin{aligned}
& \mathrm{R}^{2}=.99 \\
& \mathrm{DW}=2.34 \\
& \mathrm{R}^{2}=.99 \\
& \mathrm{DW}=2.34
\end{aligned}
$$

( $t$-values in parentheses)

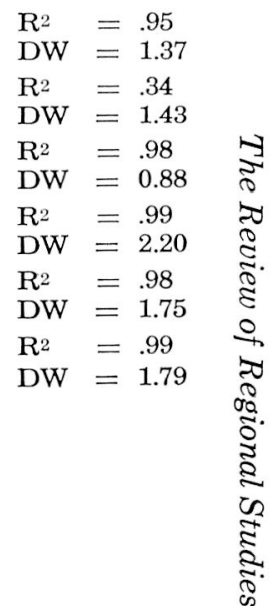




\section{TABLE 4}

\section{GLOSSARY OF VARIABLE NAMES}

Variable Prefixes (These prefixes indicate what type of economic or demographic variable is being measured)

$\mathrm{Y} \mathrm{xxx}$ indicates the variable measures regional income by industry of origin (in constant dollars), used only in the Detroit Region

$\mathrm{E} \mathrm{xxx}$ indicates the variable measures regional employment by industry (note that the construction industry symbols exclude the $\mathrm{E}$ because they always measure employment)

$\mathrm{L} \mathrm{xxx}$ indicates the variable which follows is lagged by one year (i.e., for the year 1960 the value of the variable in 1959 is used, etc.)

SH xxx indicates the variable measures U.S. value of shipments in constant dollars

POP $\mathrm{xxx}$ indicates the variable measures population. The suffix designates the specific region involved.

LOG $\mathrm{xxx}$ indicates the variable is measured as a natural logarithm for purposes of estimation.

Variable Suffixes (in alphabetical order)

CFT Carpentering and Flooring Contractors (SIC 175)

CHEM Chemicals and Allied Products (SIC 28)

CONST Aggregate of a Region's Construction Industries ${ }^{3}$ (SIC 15-17)

DUMSF Small-Firm Dummy Variable ${ }^{1}(1959-65=1,1966$ and forward =0).

EWC Electrical Work Contractors (SIC 173)

EXP Aggregate of a Region's Export Industries ${ }^{2}$

FABM Fabricated Metals Industries (SIC 34)

FURN Furniture and Fixtures Industry (SIC 25)

GBC General Business Contractors (SIC 15)

HCC Heavy Construction Contractors (SIC 16)

LOSR Aggregate of a Region's Private Local Service Industries ${ }^{2}$

MACH Machinery (except electrical) Industries (SIC 35)

MTC Miscellaneous Special Trade Contractors (SIC 172, 174, 176-9)

MV Motor Vehicles and Equipment (SIC 371)

PHC Plumbing, Heating, and Air Conditioning Contractors (SIC 171)

PRIM Primary Metals Industries (SIC 33)

PUB Aggregate of a Region's Public Sector (federal, state, and local government)

SPEC Special Trade Contractors ${ }^{3}$ (SIC 17)

TIME Linear Trend Variable $(1958=0,1959=1,1960=2$, etc.)

(1/Time) The Reciprocal of TIME

1Michigan Employment Security Commission did not require firms with less than four employees to report their employment until January 1, 1966. This variable adjusts for that discrepancy in the years in the data period which precede 1966, namely 1959 through 1965.

2The industries which comprise this variable vary from region to region. In general, all industries which are not designated as export industries (EXP), public industries (PUB), or construction industries, are included in the local service category (LOSR).

$3 \mathrm{SPEC}=\mathrm{PHC}+\mathrm{EWC}+\mathrm{CFT}+\mathrm{MTC}$

CONST $=\mathrm{GBC}+\mathrm{HCC}+\mathrm{SPEC}$ 
TABLE 5

MANPOWER REQUIREMENTS BY INDUSTRY IN THE DETROIT REGION PROJECTED TO THE YEAR 1980*

\begin{tabular}{|c|c|c|c|c|c|c|c|c|c|}
\hline INDUSTRIAL SECTOR & 1972 & 1973 & 1974 & 1975 & 1976 & 1977 & 1978 & 1979 & 1980 \\
\hline \multicolumn{10}{|c|}{ HIGH GROWTH RATES } \\
\hline Export** & 8625067 & 9047856 & 9274763 & 9475336 & 9675804 & 9879898 & 10088231 & 10301004 & 10518349 \\
\hline Private Local Services*** & 8423869 & 8817253 & 9147171 & 9452815 & 9739144 & 10010909 & 10272021 & 10525626 & 10774257 \\
\hline Public Services** & 1941414 & 2048389 & 2144245 & 2243711 & 2344705 & 2445882 & 2546441 & 2645958 & 2744275 \\
\hline Contract Construction & 65159 & 68661 & 71790 & 74560 & 76904 & 78938 & 80758 & 82446 & 84057 \\
\hline General Building & 15967 & 17031 & 17864 & 18530 & 19077 & 19545 & 19961 & 20347 & 20717 \\
\hline Heavy Construction & 6919 & 6923 & 6929 & 6935 & 6940 & 6944 & 6947 & 6952 & 6955 \\
\hline Special Trades & 42277 & 44707 & 46998 & 49095 & 50887 & 52449 & 53851 & 55148 & 56385 \\
\hline Plumbing \& Heating & 9256 & 9606 & 10265 & 10802 & 11242 & 11610 & 11929 & 12215 & 12482 \\
\hline Electrical Work & 7515 & 7796 & 8338 & 8840 & 9281 & 9663 & 9998 & 10299 & 10578 \\
\hline Carpentry \& Flooring & 4445 & 4920 & 5159 & 5421 & 5649 & 5854 & 6044 & 6225 & 6401 \\
\hline Miscellaneous Trades & 21061 & 22384 & 23236 & 24032 & 24715 & 25322 & 25881 & 26410 & 26924 \\
\hline \multicolumn{10}{|c|}{ MEDIUM GROWTH RATES } \\
\hline Export** & 8625067 & 8923714 & 9006844 & 9058269 & 9106129 & 9154360 & 9203540 & 9253786 & 9305152 \\
\hline Private Local Services** & 8423869 & 8790355 & 9067745 & 9299329 & 9493738 & 9658684 & 9800423 & 9923948 & 10033242 \\
\hline Public Services** & 1941414 & 2046452 & 2136959 & 2226769 & 2313337 & 2395164 & 2471490 & 2542057 & 2606948 \\
\hline Contract Construction & 65159 & 68245 & 70588 & 72287 & 73353 & 73966 & 74270 & 74379 & 74371 \\
\hline General Building & 15967 & 16906 & 17508 & 17871 & 18065 & 18148 & 18160 & 18131 & 18081 \\
\hline Heavy Construction & 6919 & 6923 & 6929 & 6935 & 6940 & 6944 & 6947 & 6952 & 6955 \\
\hline Special Trades & 42277 & 44416 & 46151 & 47481 & 48348 & 48874 & 49163 & 49296 & 49336 \\
\hline Plumbing \& Heating & 9256 & 9554 & 10097 & 10464 & 10690 & 10815 & 10870 & 10880 & 10863 \\
\hline Electrical Work & 7515 & 7751 & 8190 & 8533 & 8770 & 8916 & 8991 & 9018 & 9013 \\
\hline Carpentry \& Flooring & 4445 & 4870 & 5024 & 5177 & 5280 & 5347 & 5391 & 5420 & 5441 \\
\hline Miscellaneous Trades & 21061 & 22240 & 22840 & 23307 & 23608 & 23797 & 23911 & 23978 & 24019 \\
\hline \multicolumn{10}{|c|}{ LOW GROWTH RATES } \\
\hline Export** & 8625067 & 8799381 & 8743459 & 8656054 & 8567323 & 8481418 & 8398892 & 8319798 & 8244124 \\
\hline Private Local Services*** & 8423869 & 8763416 & 8989271 & 9149818 & 9258180 & 9325682 & 9361445 & 9372728 & 9365300 \\
\hline Public Services** & 1941414 & 2044511 & 2129738 & 2210164 & 2282953 & 2346626 & 2400648 & 2445111 & 2480501 \\
\hline Contract Construction & 65159 & 67827 & 69401 & 70075 & 69952 & 69279 & 68254 & 67028 & 65707 \\
\hline General Building & 15967 & 16780 & 17157 & 17230 & 17097 & 16834 & 16495 & 16118 & 15730 \\
\hline Heavy Construction & 6919 & 6923 & 6929 & 6935 & 6940 & 6944 & 6947 & 6952 & 6955 \\
\hline Special Trades & 42277 & 44124 & 45315 & 45910 & 45915 & 45501 & 44812 & 43958 & 43021 \\
\hline Plumbing \& Heating & 9256 & 9503 & 9932 & 10134 & 10160 & 10062 & 9884 & 9657 & 9407 \\
\hline Electrical Work & 7515 & 7707 & 8043 & 8233 & 8279 & 8208 & 8052 & 7842 & 7601 \\
\hline Carpentry \& Flooring & 4445 & 4819 & 4891 & 4941 & 4927 & 4870 & 4788 & 4690 & 4585 \\
\hline Miscellaneous Trades & 21061 & 22095 & 22449 & 22602 & 22549 & 22361 & 22089 & 21769 & 21429 \\
\hline
\end{tabular}

*BASED ON THREE ALTERNATIVE SETS OF ASSUMPTIONS CONCERNING THE GROWTH OF THE NATIONAL DEMAND FOR THE EXPORTS OF THE REGION.

**IN THE DETROIT REGION ONLY, INCOME PRODUCED BY INDUSTRY OF ORIGIN (IN THOUSANDS OF CONSTANT DOLLARS) IS

USED INSTEAD OF EMPLOYMENT TO MEASURE THE LEVEL OF ECONOMIC ACTIVITY IN THE NON-CONSTRUCTION SECTORS 
TABLE 6

MANPOWER REQUIREMENTS BY INDUSTRY IN THE STATE OF MICHIGAN PROJECTED TO THE YEAR 1980*

\begin{tabular}{|c|c|c|c|c|c|c|c|c|c|}
\hline INDUSTRIAL SECTOR & 1972 & 1973 & 1974 & 1975 & 1976 & 1977 & 1978 & 1979 & 1980 \\
\hline \multicolumn{10}{|c|}{ HIGH GROWTH RATES } \\
\hline Export & 828028 & 841074 & 876194 & 897584 & 914050 & 928917 & 943445 & 958122 & 973142 \\
\hline Private Local Services & 1506985 & 1524329 & 1571014 & 1599447 & 1621339 & 1641102 & 1660415 & 1679924 & 1699890 \\
\hline Public Services & 497145 & 505410 & 527659 & 541210 & 551642 & 561061 & 570265 & 579564 & 589079 \\
\hline Contract Construction & 127705 & 132030 & 139552 & 144889 & 149003 & 152604 & 156046 & 159484 & 162985 \\
\hline General Building & 38563 & 40187 & 42571 & 44384 & 45774 & 46970 & 48100 & 49222 & 50362 \\
\hline Heavy Construction & 15617 & 15734 & 15949 & 16105 & 16240 & 16371 & 16499 & 16629 & 16760 \\
\hline Special Trades & 73525 & 76109 & 81033 & 34401 & 86988 & 89264 & 91447 & 93634 & 95863 \\
\hline Plumbing \& Heating & 17091 & 17739 & 18840 & 19627 & 20232 & 20759 & 21261 & 21762 & 22272 \\
\hline Electrical Work & 12932 & 13404 & 14432 & 15102 & 15618 & 16076 & 16519 & 16964 & 17418 \\
\hline Carpentry \& Flooring & 6192 & 6498 & 7076 & 7472 & 7777 & 8045 & 8302 & 8559 & 8821 \\
\hline Miscellaneous Trades & 37311 & 38468 & 40685 & 42199 & 43361 & 44384 & 45366 & 46350 & 47352 \\
\hline \multicolumn{10}{|c|}{ MEDIUM GROWTH RATES } \\
\hline Export & 828028 & 833675 & 859217 & 870003 & 875265 & 878481 & 880961 & 883201 & 885391 \\
\hline Private Local Services & 1506985 & 1514492 & 1548446 & 1562783 & 1569779 & 1574054 & 1577350 & 1580328 & 1583240 \\
\hline Public Services & 497145 & 500722 & 516904 & 523737 & 527071 & 529108 & 530679 & 532099 & 533486 \\
\hline Contract Construction & 127705 & 130607 & 136078 & 139055 & 140638 & 141592 & 142289 & 142893 & 143469 \\
\hline General Building & 38563 & 39759 & 41484 & 42525 & 43081 & 43401 & 43621 & 43804 & 43975 \\
\hline Heavy Construction & 15617 & 15701 & 15874 & 15983 & 16070 & 16149 & 16225 & 16299 & 16374 \\
\hline Special Trades & 73525 & 75146 & 78720 & 80547 & 81487 & 82042 & 82444 & 82789 & 83119 \\
\hline Plumbing \& Heating & 17091 & 17531 & 18329 & 18767 & 18996 & 19130 & 19225 & 19305 & 19381 \\
\hline Electrical Work & 12932 & 13196 & 13943 & 14296 & 14475 & 14581 & 14660 & 14730 & 14796 \\
\hline Carpentry \& Flooring & 6192 & 6385 & 6805 & 7020 & 7131 & 7197 & 7244 & 7285 & 7324 \\
\hline Miscellaneous Trades & 37311 & 38034 & 39643 & 40463 & 40885 & 41134 & 41315 & 41470 & 41618 \\
\hline \multicolumn{10}{|c|}{ LOW GROWTH RATES } \\
\hline Export & 828028 & 826431 & 842881 & 843965 & 839374 & 832758 & 825488 & 818082 & 810732 \\
\hline Private Local Services & 1506985 & 1504862 & 1526731 & 1528170 & 1522068 & 1513273 & 1503609 & 1493764 & 1483993 \\
\hline Public Services & 497145 & 496133 & 506555 & 507241 & 504333 & 500141 & 495536 & 490843 & 486187 \\
\hline Contract Construction & 127705 & 129213 & 132732 & 133538 & 132877 & 131579 & 130037 & 128422 & 126803 \\
\hline General Building & 38563 & 39339 & 40438 & 40765 & 40578 & 40150 & 39626 & 39071 & 38512 \\
\hline Heavy Construction & 15617 & 15670 & 15803 & 15869 & 15912 & 15948 & 15981 & 16013 & 16046 \\
\hline Special Trades & 73525 & 74204 & 76492 & 76904 & 76387 & 75481 & 74430 & 73338 & 72246 \\
\hline Plumbing \& Heating & 17091 & 17327 & 17837 & 17953 & 17849 & 17649 & 17411 & 17162 & 16912 \\
\hline Electrical Work & 12932 & 12993 & 13472 & 13535 & 13416 & 13224 & 13008 & 12785 & 12562 \\
\hline Carpentry \& Flooring & 6192 & 6275 & 6543 & 6593 & 6532 & 6426 & 6303 & 6174 & 6046 \\
\hline Miscellaneous Trades & 37311 & 37610 & 38640 & 38823 & 38590 & 38182 & 37709 & 37218 & 36726 \\
\hline
\end{tabular}

*BASED ON THREE ALTERNATIVE SETS OF ASSUMPTIONS CONCERNING THE GROWTH OF THE NATIONAL DEMAND FOR THE EX-

PORTS OF THE STATE. 
industrial aggregation and the measure of the level of activity which are used in making the projections. If the level of industrial disaggregation is sufficiently fine to distinguish between single-family home and public school building construction, for example, and dollar volume of construction contracts is the measure of activity, then it is possible to apply available estimates of labor requirements per $\$ 1,000$ of construction contract cost for each specific type of structure.

Often, however, as in the case of the Michigan Craft Study, this level of industrial disaggregation is not available and the industry projections are made in terms of employment rather than dollar volume of construction. In this case, then, the more general approach of converting industry employment projections into manpower projections by applying an industry-occupation (I-O) matrix must be followed, as prescribed in Tomorrow's Manpower Needs. ${ }^{5}$

Each column vector of an I-O matrix provides a percentage distribution of the total employment in the corresponding industry by occupation. When these column vectors are multiplied by a scalar representing the projected industry employment for a particular year the result will be a vector of craft projections for that year.

This critical step in the manpower projection process was made difficult by the absence of appropriate current or projected regional industry-occupation matrices. The U.S. Department of Labor has projected the 1970 Census industry-occupation matrix for the United States to $1980^{\circ}$ and local manpower agencies are currently doing the same for State matrices. These available matrices are not directly applicable to any smaller region, however, because of the likely differences in industry and occupation mix among regions. Even more serious is the fact that State matrices are deficient at all levels of regional disaggregation with regard to the construction industry. This is because a large proportion of the construction labor force is comprised of travelers from other states who are counted by the Census according to the state of their legal residence and not by workplace, as required for an operational industry-occupation matrix.

Fortunately, sufficiently detailed craft employment data was made available to this Study from union pension fund records, so that it was possible to develop 1970 industry-occupation matrices for the construction sector in each of the Study Regions as well as for the State as a whole. The next step was to project these region-specific industry-occupation matrices to 1980 so that the 1980 construction industry projections could be converted to craft projections. In the absence of reliable local data, it was necessary to use "change factors" derived from the national industry-occupation matrix to capture projected changes in productivity, technology and industry structure between 1970 and 1980. A special local adjustment suggested by the Advisory Committee members was incorporated with these national change factors, however, to compute unique sets of modified change factors for the Detroit Region, for the Outstate Regions, ${ }^{10}$ and for the State as a whole.

Dunlop and Mills ${ }^{11}$ have pointed out that there is an important distinction between "year-long jobs" in construction and the number of men required to man those jobs, depending on how many hours each employee works per year and how much overtime work is allowed. The Advisory Committee adopted the view that 
the construction industry in Michigan should and would attempt to minimize the amount of overtime worked in the future and established a schedule of estimated, maximum annual manhours for members of each of the nine crafts identified in the Study.

Based on data obtained from pension fund records on average annual hours worked per man by craft for the years 1968-1972, it was possible to compute a ratio of actual hours worked in the recent past to the standardized hours adopted by the Advisory Committee, as follows:

$\begin{gathered}\text { Annual hours worked } \\ \text { adjustment factor }\end{gathered}=\frac{\text { Actual annual hours worked (1968-72) }}{\text { Standardized annual hours worked }}$

The nationally-based change factors were multiplied by these special adjustment factors to derive modified change factors which, in turn, were used to project the 1970 regional construction industry-occupation matrices to 1980 . Modified change factors for the State as a whole were developed as a weighted (by employment) average of the Detroit and Outstate modified change factors. The regional industry employment projections were then multiplied by the projected 1980 industry-occupation matrix for each region to obtain the detailed craft manpower projections, as presented in Tables 7 and 8 and summarized in Tables 9 and 10 for Detroit and the State, respectively.

Tables 9 and 10 specifically illustrate the method used in combining the demand for manpower by craft projected by each model with other demand factors, in order to forecast "total" craft manpower requirements for 1980. The difference between the actual 1970 employment figures given in the first columns of Tables 9 and 10 and the 1980 employment figures projected by the model, given in the second column, is the net number of new jobs estimated to be available in 1980. However, in order to obtain the total manpower requirements for the decade, it is necessary to take into consideration (1) extraordinary increases in demand which would not be captured by the econometric models, and (2) replacement requirements that result from craft-specific death and retirement rates.

(1) Power plant "add-on" requirements: As previously noted, the Study was initiated because Detroit Edison and Consumers Power Companies' plans for accelerated power plant construction in the State anticipated serious shortages of certain construction craftsmen. Consequently, the Study was provided with detailed, annual power plant construction manpower requirement plans by region, projected beyond 1980. However, since power plant construction had also occurred in the recent past in each of these regions, the industry employment models already incorporated some level of power plant construction and would thus project an increase in this activity commensurate with the changes projected for the rest of the region's economy. Therefore, it was necessary to reduce the power plant manpower requirements estimated by the electrical utilities for that component of power plant construction activity projected by the model, deriving a net power plant "add-on" factor. These add-on requirements appear in the fourth column of Tables 9 and 10. 
TABLE 7

MANPOWER REQUIREMENTS BY SELECTED CRAFTS IN THE DETROIT REGION

PROJECTED TO THE YEAR 1980*

\begin{tabular}{|c|c|c|c|c|c|c|c|c|c|}
\hline CRAFT & 1972 & 1973 & 1974 & 1975 & 1976 & 1977 & 1978 & 1979 & 1980 \\
\hline \multicolumn{10}{|c|}{ HIGH GROWTH RATES } \\
\hline Asbestos Workers & 343 & 358 & 374 & 391 & 408 & 426 & 445 & 464 & 484 \\
\hline Boilermakers & 429 & 450 & 472 & 495 & 519 & 545 & 571 & 599 & 629 \\
\hline Carpenters & 13100 & 13358 & 13621 & 13889 & 14162 & 14440 & 14724 & 15014 & 15309 \\
\hline Electricians & 5077 & 5289 & 5509 & 5738 & 5976 & 6225 & 6484 & 6753 & 7034 \\
\hline Ironworkers & 3388 & 3433 & 3478 & 3524 & 3571 & 3618 & 3666 & 3714 & 3763 \\
\hline Millwrights & 691 & 718 & 747 & 776 & 806 & 838 & 871 & 905 & 941 \\
\hline Operating Engineers & 4666 & 4720 & 4775 & 4830 & 4886 & 4943 & 5000 & 5058 & 5117 \\
\hline Plumbers \& Pipefitters & 4155 & 4317 & 4485 & 4659 & 4840 & 5029 & 5224 & 5427 & 5638 \\
\hline Sheetmetal Workers & 4112 & 4278 & 4450 & 4630 & 4816 & 5010 & 5212 & 5422 & 5641 \\
\hline All Crafts & 36003 & 36975 & 37974 & 38999 & 40052 & 41134 & 42244 & 43385 & 44556 \\
\hline All Others & 30380 & 31393 & 32441 & 33523 & 34641 & 35797 & 36991 & 38225 & 39500 \\
\hline Total Industry & 66388 & 68376 & 70422 & 72531 & 74702 & 76938 & 79241 & 81613 & 84056 \\
\hline \multicolumn{10}{|c|}{ MEDIUM GROWTH RATES } \\
\hline Asbestos Workers & 334 & 344 & 355 & 365 & 377 & 388 & 400 & 412 & 424 \\
\hline Boilermakers & 418 & 433 & 448 & 464 & 480 & 497 & 515 & 533 & 552 \\
\hline Carpenters & 12757 & 12836 & 12915 & 12995 & 13075 & 13156 & 13238 & 13320 & 13402 \\
\hline Electricians & 4946 & 5085 & 5228 & 5375 & 5526 & 5681 & 5840 & 6004 & 6173 \\
\hline Ironworkers & 3302 & 3303 & 3304 & 3305 & 3307 & 3308 & 3309 & 3310 & 3311 \\
\hline Millwrights & 673 & 691 & 709 & 727 & 746 & 765 & 785 & 805 & 825 \\
\hline Operating Engineers & 4608 & 4632 & 4656 & 4680 & 4705 & 4729 & 4754 & 4779 & 4804 \\
\hline Plumbers \& Pipefitters & 4049 & 4153 & 4259 & 4367 & 4479 & 4593 & 4711 & 4831 & 4954 \\
\hline Sheetmetal Workers & 4004 & 4110 & 4219 & 4330 & 4445 & 4563 & 4683 & 4807 & 4935 \\
\hline All Crafts & 35125 & 35631 & 36144 & 36664 & 37192 & 37727 & 38271 & 38822 & 39381 \\
\hline All Others & 29652 & 30272 & 30905 & 31552 & 32211 & 32885 & 33573 & 34275 & 34991 \\
\hline Total Industry & 64782 & 65910 & 67057 & 68224 & 69412 & 70620 & 71849 & 73099 & 74371 \\
\hline \multicolumn{10}{|c|}{ LOW GROWTH RATES } \\
\hline Asbestos Workers & 325 & 331 & 336 & 341 & 347 & 353 & 358 & 364 & 370 \\
\hline Boilermakers & 407 & 416 & 425 & 434 & 444 & 453 & 463 & 473 & 483 \\
\hline Carpenters & 12414 & 12323 & 12232 & 12141 & 12051 & 11962 & 11874 & 11786 & 11699 \\
\hline Electricians & 4816 & 4886 & 4956 & 5028 & 5100 & 5174 & 5249 & 5324 & 5401 \\
\hline Ironworkers & 3217 & 3177 & 3136 & 3097 & 3058 & 3019 & 2981 & 2943 & 2906 \\
\hline Millwrights & 656 & 664 & 672 & 680 & 688 & 697 & 705 & 714 & 722 \\
\hline Operating Engineers & 4553 & 4549 & 4546 & 4542 & 4538 & 4535 & 4531 & 4527 & 4524 \\
\hline Plumbers \& Pipefitters & 3944 & 3991 & 4040 & 4088 & 4138 & 4188 & 4239 & 4290 & 4342 \\
\hline Sheetmetal Workers & 3896 & 3944 & 3994 & 4043 & 4094 & 4145 & 4197 & 4249 & 4302 \\
\hline All Crafts & 34257 & 34318 & 34380 & 34441 & 34503 & 34564 & 34626 & 34688 & 34750 \\
\hline All Others & 28934 & 29180 & 29427 & 29676 & 29928 & 30182 & 30438 & 30696 & 30956 \\
\hline Total Industry & 63197 & 63505 & 63815 & 64126 & 64439 & 64754 & 65069 & 65387 & 65706 \\
\hline
\end{tabular}


TABLE 8

MANPOWER REQUIREMENTS BY SELECTED CRAFTS IN THE STATE OF MICHIGAN

PROJECTED TO THE YEAR 1980*

\begin{tabular}{|c|c|c|c|c|c|c|c|c|c|}
\hline CRAFT & 1972 & 1973 & 1974 & 1975 & 1976 & 1977 & 1978 & 1979 & 1980 \\
\hline \multicolumn{10}{|c|}{ HIGH GROWTH RATES } \\
\hline Asbestos Workers & 713 & 736 & 759 & 783 & 808 & 834 & 860 & 888 & 916 \\
\hline Boilermakers & 854 & 899 & 947 & 998 & 1051 & 1106 & 1165 & 1227 & 1292 \\
\hline Carpenters \& Millwrights & 21465 & 22050 & 22652 & 23269 & 23904 & 24556 & 25226 & 25914 & 26621 \\
\hline Electricians & 8335 & 8682 & 9045 & 9422 & 9816 & 10225 & 10652 & 11097 & 11560 \\
\hline Ironworkers & 5250 & 5321 & 5393 & 5466 & 5540 & 5616 & 5692 & 5769 & 5847 \\
\hline Operating Engineers & 9796 & 9985 & 10177 & 10372 & 10572 & 10775 & 10982 & 11194 & 11409 \\
\hline Plumbers \& Pipefitters & 7596 & 7870 & 8154 & 8449 & 8754 & 9070 & 9397 & 9737 & 10088 \\
\hline Sheetmetal Workers & 6106 & 6377 & 6659 & 6954 & 7262 & 7584 & 7920 & 8271 & 8637 \\
\hline All Crafts & 60159 & 61980 & 63857 & 65790 & 67782 & 69834 & 71948 & 74127 & 76371 \\
\hline All Others & 64278 & 66720 & 69254 & 71885 & 74615 & 77449 & 80391 & 83444 & 86614 \\
\hline Total Industry & 124451 & 128718 & 133133 & 137698 & 142420 & 147304 & 152356 & 157580 & 162984 \\
\hline \multicolumn{10}{|c|}{ MEDIUM GROWTH RATES } \\
\hline Asbestos Workers & 693 & 705 & 718 & 730 & 743 & 756 & 769 & 782 & 795 \\
\hline Boilermakers & 831 & 863 & 896 & 931 & 967 & 1004 & 1043 & 1083 & 1125 \\
\hline Carpenters \& Millwrights & 20887 & 21166 & 21449 & 21736 & 22026 & 22320 & 22619 & 22921 & 23227 \\
\hline Electricians & 8105 & 8326 & 8554 & 8787 & 9027 & 9274 & 9527 & 9787 & 10055 \\
\hline Ironworkers & 5110 & 5110 & 5111 & 5111 & 5111 & 5111 & 5111 & 5111 & 5111 \\
\hline Operating Engineers & 9648 & 9760 & 9872 & 9986 & 10101 & 10217 & 10335 & 10454 & 10574 \\
\hline Plumbers \& Pipefitters & 7389 & 7551 & 7716 & 7885 & 8057 & 8234 & 8414 & 8598 & 8786 \\
\hline Sheetmetal Workers & 5935 & 6110 & 6291 & 6477 & 6668 & 6865 & 7068 & 7277 & 7492 \\
\hline All Crafts & 58633 & 59638 & 60659 & 61698 & 62755 & 63830 & 64923 & 66035 & 67166 \\
\hline All Others & 62669 & 64230 & 65830 & 67470 & 69150 & 70873 & 72638 & 74447 & 76302 \\
\hline Total Industry & 121316 & 123886 & 126511 & 1291.91 & 131928 & 134723 & 137577 & 140491 & 143467 \\
\hline \multicolumn{10}{|c|}{ LOW GROWTH RATES } \\
\hline Asbestos Workers & 675 & 677 & 680 & 682 & 684 & 687 & 689 & 692 & 694 \\
\hline Boilermakers & 809 & 829 & 850 & 871 & 893 & 915 & 938 & 961 & 985 \\
\hline Carpenters \& Millwrights & 20342 & 20343 & 20343 & 20344 & 20345 & 20346 & 20347 & 20348 & 20349 \\
\hline Electricians & 7891 & 7998 & 8107 & 8218 & 8330 & 8443 & 8558 & 8675 & 8793 \\
\hline Ironworkers & 4980 & 4916 & 4853 & 4791 & 4729 & 4668 & 4609 & 4549 & 4491 \\
\hline Operating Engineers & 9516 & 9560 & 9604 & 9647 & 9692 & 9736 & 9780 & 9825 & 9870 \\
\hline Plumbers \& Pipefitters & 7196 & 7256 & 7317 & 7379 & 7441 & 7504 & 7567 & 7630 & 7695 \\
\hline Sheetmetal Workers & 5774 & 5864 & 5955 & 6047 & 6141 & 6237 & 6334 & 6432 & 6532 \\
\hline All Crafts & 57211 & 57481 & 57753 & 58025 & 58299 & 58575 & 58851 & 59129 & 59408 \\
\hline All Others & 61169 & 61938 & 62716 & 63504 & 64302 & 65110 & 65928 & 66757 & 67596 \\
\hline Total Industry & 118394 & 119438 & 120490 & 121552 & 122623 & 123704 & 124794 & 125894 & 127003 \\
\hline
\end{tabular}

*BASED ON THREE ALTERNATIVE SETS OF ASSUMPTIONS CONCERNING THE GROWTH OF THE NATIONAL DEMAND FOR THE

EXPORTS OF THE STATE. 
TABLE 9

CRAFT MANPOWER REQUIREMENTS PROJECTED TO THE YEAR 1980 DETROIT REGION

\begin{tabular}{|c|c|c|c|c|c|c|c|}
\hline \multirow{3}{*}{$\begin{array}{c}\text { Craft } \\
\text { (Alternative } \\
\text { Growth Rates) }\end{array}$} & \multicolumn{2}{|c|}{ Total Employment } & \multicolumn{5}{|c|}{ Change in Requirements $1970-80$} \\
\hline & \multirow{2}{*}{$\begin{array}{l}\text { Actual } \\
1970\end{array}$} & \multirow{2}{*}{$\begin{array}{c}\text { Projected } \\
1980\end{array}$} & \multicolumn{2}{|c|}{ New Jobs } & \multirow{2}{*}{$\begin{array}{l}\text { Replace- } \\
\text { ment }\end{array}$} & \multirow{2}{*}{$\begin{array}{r}\text { Total } \\
1970-80 \text { Per }\end{array}$} & \multirow[b]{2}{*}{ Year $^{3}$} \\
\hline & & & Model & Add-On ${ }^{2}$ & & & \\
\hline Asbestos Workers & 315 & & & & & & \\
\hline High & & 480 & 165 & - & 30 & 195 & 20 \\
\hline Medium & & 420 & 105 & - & 30 & 135 & 15 \\
\hline Low & & 370 & 55 & 一 & 30 & 85 & 10 \\
\hline Boilermakers & 390 & & & & & & \\
\hline High & & 630 & 240 & $(380)$ & 115 & (25) & 一 \\
\hline Medium & & 550 & 160 & (325) & 115 & (50) & 一 \\
\hline Low & & 480 & 90 & $(270)$ & 115 & (65) & 一 \\
\hline Carpenters & 12,600 & & & & & & \\
\hline High & & 15,310 & 2,710 & 一 & 1,135 & 3,845 & 385 \\
\hline Medium & & 13,400 & 800 & - & 1,135 & 1,935 & 195 \\
\hline Low & & 11,700 & $(900)$ & - & 1,135 & 235 & 25 \\
\hline Millwrights & 640 & & & & & & \\
\hline High & & 940 & 300 & - & 135 & 435 & 45 \\
\hline Medium & & 830 & 190 & - & 135 & 325 & 35 \\
\hline Low & & 720 & 80 & 一 & 135 & 215 & 20 \\
\hline Electricians & 4,680 & & & & & & \\
\hline High & & 7,030 & 2,350 & 225 & 750 & 3,325 & 330 \\
\hline Medium & & 6,170 & 1,490 & 280 & 750 & 2,520 & 250 \\
\hline Low & & 5,400 & 720 & 330 & 750 & 1,800 & 180 \\
\hline Ironworkers & 3,300 & & & & & & \\
\hline High & & 3,760 & 460 & - & 600 & 1,060 & 105 \\
\hline Medium & & 3,310 & 10 & - & 600 & 610 & 60 \\
\hline Low & & 2,910 & $(390)$ & - & 600 & 210 & 20 \\
\hline Operating Engrs. & 4,560 & & & & & & \\
\hline High & & 5,120 & 560 & - & 740 & 1,300 & 130 \\
\hline Medium & & 4,800 & 240 & - & 740 & 980 & 100 \\
\hline Low & & 4,520 & $(40)$ & - & 740 & 700 & 70 \\
\hline Plumbers \& Pipefitters & 3,850 & & & & & & \\
\hline High & & 5,640 & 1,790 & 180 & 990 & 2,960 & 295 \\
\hline Medium & & 4,950 & 1,100 & 240 & 990 & 2,330 & 235 \\
\hline Low & & 4,340 & 490 & 300 & 990 & 1,780 & 180 \\
\hline Sheetmetal Workers & 3,800 & & & & & & \\
\hline High & & 5,640 & 1,840 & - & 625 & 2,465 & 245 \\
\hline Medium & & 4,940 & 1,140 & - & 625 & 1,765 & 175 \\
\hline Low & & 4,300 & 500 & - & 625 & 1,125 & 110 \\
\hline All Others & 28,450 & & & & & & \\
\hline High & & 39,500 & 11,050 & - & 6,000 & 17,050 & 1,705 \\
\hline Medium & & 34,990 & 6,540 & 一 & 6,000 & 12,540 & 1,255 \\
\hline Low & & 30,960 & 2,510 & - & 6,000 & 8,510 & 850 \\
\hline Total Industry ${ }^{1}$ & 62,585 & & & & & & \\
\hline High & & 84,060 & 21,475 & 25 & 11,120 & 32,620 & 3,260 \\
\hline Medium & & 74,370 & 11,785 & 195 & 11,120 & 23,100 & 2,310 \\
\hline Low & & 65,700 & 3,115 & 360 & 11,120 & 14,595 & 1,460 \\
\hline
\end{tabular}

1Non-additive totals due to rounding.

2 Add-On power plant requirements.

3 Average per year requirements are rounded to the nearest 5 craftsmen.

(2) Replacement demand: Since the number of retirements and deaths in any given period is a function of the age distribution of the employees, it was necessary to obtain detailed, region-specific, actuarial information on the age dis- 
TABLE 10

CRAF'T MANPOWER REQUIREMENTS PROJECTED TO THE YEAR 1980 STATE OF MICHIGAN

\begin{tabular}{|c|c|c|c|c|c|c|c|}
\hline \multirow{3}{*}{$\begin{array}{c}\text { Craft } \\
\text { (Alternative } \\
\text { Growth Rates) }\end{array}$} & \multicolumn{2}{|c|}{ Total Employment } & \multicolumn{5}{|c|}{ Change in Requirements $1970-80$} \\
\hline & \multirow{2}{*}{$\begin{array}{l}\text { Actual } \\
1970\end{array}$} & \multirow{2}{*}{$\begin{array}{c}\text { Projected } \\
1980\end{array}$} & \multicolumn{2}{|c|}{ New Jobs } & \multirow{2}{*}{$\begin{array}{l}\text { Replace- } \\
\text { ment }\end{array}$} & \multirow{2}{*}{\multicolumn{2}{|c|}{$\begin{array}{c}\text { Total } \\
1970-80 \text { Per Year }\end{array}$}} \\
\hline & & & Model & Add- $-\mathrm{n}^{2}$ & & & \\
\hline Asbestos Workers & 670 & & & & & & \\
\hline High & & 920 & 250 & - & 100 & 350 & 35 \\
\hline Medium & & 800 & 130 & - & 100 & 230 & 25 \\
\hline Low & & 690 & 20 & - & 100 & 120 & 10 \\
\hline Boilermakers & 770 & & & & & & \\
\hline High & & 1,290 & 520 & (335) & 225 & 410 & 40 \\
\hline Medium & & 1,120 & 350 & (255) & 225 & 320 & 30 \\
\hline Low & & 990 & 220 & (175) & 225 & 270 & 25 \\
\hline Carpenters \& Millwgts. & 20,340 & & & & & & \\
\hline High & & 26,620 & 6,280 & - & 4,100 & 10,380 & 1,040 \\
\hline Medium & & 23,230 & 2,890 & - & 4,100 & 6,990 & 700 \\
\hline Low & & 20,350 & 10 & - & 4,100 & 4,110 & 410 \\
\hline Electricians & 7,680 & & & & & & \\
\hline High & & 11,560 & 3,880 & 870 & 1,500 & 6,250 & 625 \\
\hline Medium & & 10,060 & 2,380 & 940 & 1,500 & 4,820 & 480 \\
\hline Low & & 8,790 & 1,110 & 1,005 & 1,500 & 3,615 & 360 \\
\hline Ironworkers & 5,110 & & & & & & \\
\hline High & & 5,850 & 740 & - & 1,100 & 1,840 & 185 \\
\hline Medium & & 5,110 & - & - & 1,100 & 1,100 & 110 \\
\hline Low & & 4,490 & (620) & - & 1,100 & 480 & 50 \\
\hline Operating Engrs. & 9,430 & & & & & & \\
\hline High & & 11,410 & 1,980 & - & 1,530 & 3,510 & 350 \\
\hline Medium & & 10,570 & 1,140 & - & 1,530 & 2,670 & 265 \\
\hline Low & & 9,870 & 440 & - & 1,530 & 1,970 & 195 \\
\hline Plumbers \& Pipefitters & 7,076 & & & & & & \\
\hline High & & 10,090 & 3,010 & 1,060 & 1,500 & 5,570 & 555 \\
\hline Medium & & 8,790 & 1,710 & 1,130 & 1,500 & 4,340 & 435 \\
\hline Low & & 7,700 & 620 & 1,200 & 1,500 & 3,320 & 330 \\
\hline Sheetmetal Workers & 5,599 & & & & & & \\
\hline High & & 8,640 & 3,040 & - & 1,160 & 4,200 & 420 \\
\hline Medium & & 7,490 & 1,890 & - & 1,160 & 3,050 & 305 \\
\hline Low & & 6,530 & 930 & 一 & 1,160 & 2,090 & 210 \\
\hline All Others & 59,660 & & & & & & \\
\hline High & & 86,600 & 26,940 & - & 10,800 & 37,740 & 3,775 \\
\hline Medium & & 76,300 & 16,640 & - & 10,800 & 27,440 & 2,745 \\
\hline Low & & 67,600 & 7,930 & - & 10,800 & 18,730 & 1,875 \\
\hline Total Industry 1 & 116,335 & & & & & & \\
\hline High & & 162,980 & 46,640 & 1,600 & 22,000 & 70,240 & 7,025 \\
\hline Medium & & 143,470 & 27,130 & 1,820 & 22,000 & 50,950 & 5,095 \\
\hline Low & & 127,000 & 10,660 & 2,030 & 22,000 & 34,690 & 3,470 \\
\hline
\end{tabular}

1Non-additive totals due to rounding.

2Add-On power plant requirements.

3 Average per year requirements are rounded to the nearest five craftsmen.

tribution of the craftsmen as well as some information about past retirees. Craftspecific replacement (death and retirement) rates were computed for most of the crafts on the basis of this local actuarial data, utilizing the U.S. Public Health Service's national five-year survival rates by occupation to capture the expected mortality experience by craft. These replacement rates were applied to the 1970 
employment data by craft to obtain the number of replacements required to 1970, which is presented in the fifth column of Tables 9 and 10.

The three demand components were then summed to obtain the total number of new craftsmen needed by 1980, as shown in the sixth column of Tables 9 and 10. Dividing this figure by ten gives the average number of additional craftsmen that must be employed per year to reach the projected 1980 levels-these figures are given in the last column.

\section{Projecting the Supply of Each Craft by Region and Evaluating Potential Shortages or Surpluses}

The supply side of most manpower studies is either missing completely or in a serious state of underdevelopment. Although this Study cannot claim to have developed a satisfactory supply model, it has benefited from the availability of relatively detailed data on apprenticeship programs by craft and region.

The following are the primary sources of supply for construction craftsmen: (1) formal and informal apprenticeship training programs, (2) permit (white card) men-members of construction craft who are given a white temporary permit card authorizing them to do the work of another construction craft, (3) travelers - journeymen members of a craft who migrate to work in a region beyond the boundaries of the local union in which they hold membership, (4) journeymen with the same craft skill but working in a non-construction industry and who belong to a different international union, e.g., U.A.W. sheetmetal workers who leave the motor vehicle industry to work in the contract construction industry and become members of the A. F. of L. Sheetmetal Workers, (5) unemployed craftsmen, and (6) retired craftsmen.

The latter two are important short-run sources of supply but are less significant in long-run analysis - the focus of this Study. While travelers and permit men can be a very important source of supply, not only in the short-run but also in the long-run, data limitations did not permit a formal consideration of these source. And since interindustry mobility was not considered to be an important factor by construction industry experts, the supply analysis was limited to a consideration of the adequacy of the apprenticeship programs for the nine crafts identified in the Study.

Table 11 summarizes the annual monthly average enrollments of apprentices in formal training programs conducted in the Detroit Region and in the rest of the State in recent years. There are no formal apprenticeship programs for asbestos workers anywhere in the State. While the boilermakers and operating engineers each have only one State-wide union, there is some regionalization of their apprenticeship programs.

Below is a summary of the anticipated imbalance between supply (Table 11) and demand (Tables 9 and 10) for the three regions within Michigan with substantial planned power plant construction and for the State as a whole. 
TABLE 11

ENROLLMENT IN APPRENTICESHIP TRAINING PROGRAMS

\begin{tabular}{cccc}
\hline & \multicolumn{3}{c}{ Average Monthly Enrollment } \\
\cline { 2 - 4 } & $\begin{array}{l}\text { Detroit } \\
\text { Region }\end{array}$ & Outstate & Total \\
Regions & State & State
\end{tabular}

Asbestos Workers

Boilermakers

1971

1972

1973

Carpenters

1969

1970

1971

1972

1973

Electricians

1969

1970

1971

1972

1973

Ironworkers

1969

1970

1971

1972

1973

Operating Engineers

1973

Plumbers and Pipefitters

1969

1970

1971

1972

1973
No formal training program

$\begin{array}{lll}44^{*} & 19 & 63 \\ 31^{*} & 28 & 59 \\ 31^{*} & 40 & 71\end{array}$

1,055

783

675

627

519

330

299

290

1,385

1,082

965

869

733

214

277

738

461

266

770

571

211

169

202

782

733

581

783

205

202

407

201

225

178

379

409

487

263

184

482

34

80

114

734

505

1,239

780

455

1,235

667

645

368

1,035

328

973

611

338

949

Sheetmetal Workers**

1973

75

98

173

Source: Various agencies and apprenticeship programs. For details, see J. M. Mattila and J. R. Moor, Jr., Michigan Building and Construction Trades Craft Manpower Study. (Detroit: Citizens Research Council of Michigan, 1974), especially Tables 13 and 14.

*Includes the Flint Region.

**Programs discontinued from 1970 through 1972. 


\section{ANTICIPATED SUPPLY AND DEMAND RELATIONSHIPS FOR BOILERMAKERS, ELECTRICIANS AND PIPEFITTERS}

\begin{tabular}{|c|c|c|c|c|}
\hline Craft & Detroit & $\begin{array}{l}\text { Bay City- } \\
\text { Midland- } \\
\text { Saginaw }\end{array}$ & $\begin{array}{l}\text { Grand Rapids- } \\
\text { Muskegon }\end{array}$ & State \\
\hline Boilermakers & $\begin{array}{l}\text { Small } \\
\text { surplus }\end{array}$ & $\begin{array}{l}\text { Small } \\
\text { shortage }\end{array}$ & $\begin{array}{l}\text { Small } \\
\text { shortage }\end{array}$ & $\begin{array}{l}\text { Small } \\
\text { shortage }\end{array}$ \\
\hline Electricians & $\begin{array}{l}\text { Moderate } \\
\text { shortage }\end{array}$ & $\begin{array}{c}\text { Substantial } \\
\text { shortage }\end{array}$ & $\begin{array}{l}\text { Small } \\
\text { shortage }\end{array}$ & $\begin{array}{c}\text { Substantial } \\
\text { shortage }\end{array}$ \\
\hline $\begin{array}{c}\text { Plumbers and } \\
\text { Pipefitters }\end{array}$ & $\begin{array}{c}\text { Substantial } \\
\text { shortage }\end{array}$ & $\begin{array}{c}\text { Substantial } \\
\text { shortage }\end{array}$ & $\begin{array}{c}\text { Substantial } \\
\text { shortage }\end{array}$ & $\begin{array}{c}\text { Substantial } \\
\text { shortage }\end{array}$ \\
\hline
\end{tabular}

The estimates of potential supply are based on the assumption that the apprenticeship programs remain at their current levels of enrollment. Electricians and plumbers and pipefitters appear to be the two crafts which could experience substantial shortages unless their apprenticeship programs are expanded to allow larger numbers of apprentices to enter each year. A less severe shortage of boilermakers is anticipated, but this is a craft in which approximately one-half of Michigan's employment consists of travelers from other states, and it may be desirable to reduce the dependency on this external source of supply by expanding the apprenticeship program.

The alternative (high, medium, and low) industry and craft employment projections presented in Tables 5-8 reveal that the methodology outlined in this paper does yield quite stable results, even when a fairly wide range of alternative assumptions regarding the growth rates of the national demand for the region's exports are used to derive these alternative projections. These national growth rates are the key exogenous "shocks" which "drive" the models. Indeed, it is this feature which truly distinguishes the Michigan Craft Study - the linking of construction manpower demand projections to those factors which determine the level and rate of growth of local economic activity.

The Michigan Craft Study has demonstrated one practical application of regional economic theory and forecasting techniques to manpower planning. The flexible design of the regional economic models developed for the Study permits timely adjustments to be made for unanticipated changes in regional or national conditions (for example, the so-called "energy crisis"), as well as for periodic updates and revisions. While updated industry employment data is readily available from State Employment Security Agencies, periodic occupational data must be obtained from union pension fund sources which are only accessible if both labor and management agree jointly to the release of such data. Additionally, extraordinary sources of manpower demand can only be identified if major users of contract construction labor cooperate to reveal their past and projected manpower requirements for major plant expansion projects. The Study has emphasized the 
importance of full cooperation among all concerned elements--Building Trades Unions, Contractors Associations and User's Councils.

The Study has provided a rationalized regional economic model which can be refined and expanded to include other important aspects of regional planning. These aspects include, but certainly are not limited to, population forecasting, land-use patterns, and transportation systems. Much also remains to be done in the narrower context of manpower planning. As mentioned above, improvement is needed in the analysis of the supply side of manpower planning, including the Michigan Craft Study. On the demand side, the regional models would be much more sensitive to local changes in contract construction activity if the general building contractor's sector of the industry could be further disaggregated into residential, commercial and industrial construction. Unfortunately, the industryoccupation matrices that are so critical in the process of converting industry employment into craft employment will not benefit markedly from the forthcoming State industry-occupation matrices that will be based on 1970 Census of Population data. Therefore, construction manpower studies will have to continue to devote much time and energy to perfecting local industry-occupation matrices and to properly account for anticipated changes in productivity and technology which affect the demand for the various crafts over time. Clearly, the application of regional economic modeling to manpower planning has just begun.

\section{FOOTNOTES}

1B. Ahamad and M. Blaug, The Practice of Manpower Forecasting, A Collection of Case Studies, (San Francisco: Jossey-Bass, Inc., 1973).

2D. Q. Mills, Industrial Relations and Manpower in Construction, (Cambridge: The M.I.T. Press, 1972).

3Ibid., p. 111.

ঊ. M. Mattila and J. R. Moor, Michigan Building and Construction Trades Craft Manpower Study (Detroit: Citizens Research Council of Michigan, 1974).

5 U.S. Department of Labor, Bureau of Labor Statistics, Tomorrow's Manpower Needs, Research Report on Manpower Projection Methods, Bulletin 1769, (Washington, D. C.: GPO, 1973).

6For further details on the specific methodology and the detailed findings see Mattila and Moor, Michigan Building and Construction Trades Craft Manpower Study.

iMills, Industrial Relations and Manpower in Construction, pp. 114-117.

8In the Detroit region, metropolitan income, as estimated by John M. Mattila, was used in place of employment for the export and local sectors only (e.g., Detroit motor vehicle activity-YMV). See J. M. Mattila, "Metropolitan Income Estimation," Urban Affairs Quarterly, Vol. 6, December, 1970, pp. 179-197. 1971).

9 U. S. Department of Labor, Tomorrows Manpower Needs, Vol. IV Revised, (Washington, D. C.: GOP,

${ }_{10}$ According to common usage in Michigan, "Outstate" refers to the entire State excepting the southeastern counties which comprise the Greater Detroit area.

11 J. T. Dunlop and D. Q. Mills, Manpower in Construction: A Profile of the Industry and Projections to 1975, (Washington, D. C.: President's Committee on Urban Housing, Technical Studies, Vol. 2, 1968). 